\title{
CYP2D6*8 Allele
}

National Cancer Institute

\section{Source}

National Cancer Institute. CYP2D6*8 Allele. NCI Thesaurus. Code C45623.

Human CYP2D6*8 allele is located in the vicinity of $22 q 13.1$ and is approximately $4 \mathrm{~kb}$ in length. This allele, a variant form of the CYP2D6 wild-type allele, encodes cytochrome P450 2D6*8 protein. The CYP2D6*8 allele exhibits a clinically-relevant SNP (g.1758G>T) in exon 3 that generates a stop codon. This alteration yields a truncated cytochrome P450 2D6*8 protein that is enzymatically inactive. 